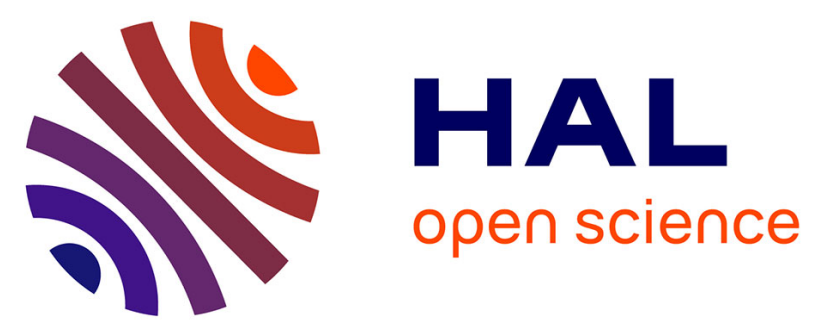

\title{
Optimal Condition for Determination of Zinc Bacitracin, Polymyxin B, Oxytetracycline and Sulfacetamide in Animal Feed by Micellar Electrokinetic Capillary Chromatography
}

Rade Dragan Injac, Ales Mlinaric, Vukosava Djordjevic-Milic, Katarina Karljikovic-Rajic, Borut Strukelj

\section{To cite this version:}

Rade Dragan Injac, Ales Mlinaric, Vukosava Djordjevic-Milic, Katarina Karljikovic-Rajic, Borut Strukelj. Optimal Condition for Determination of Zinc Bacitracin, Polymyxin B, Oxytetracycline and Sulfacetamide in Animal Feed by Micellar Electrokinetic Capillary Chromatography. Food Additives and Contaminants, 2008, 25 (04), pp.424-431. 10.1080/02652030701584058 . hal-00577424

HAL Id: hal-00577424

https://hal.science/hal-00577424

Submitted on 17 Mar 2011

HAL is a multi-disciplinary open access archive for the deposit and dissemination of scientific research documents, whether they are published or not. The documents may come from teaching and research institutions in France or abroad, or from public or private research centers.
L'archive ouverte pluridisciplinaire HAL, est destinée au dépôt et à la diffusion de documents scientifiques de niveau recherche, publiés ou non, émanant des établissements d'enseignement et de recherche français ou étrangers, des laboratoires publics ou privés. 


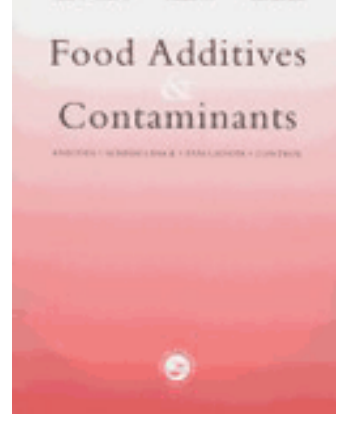

\section{Optimal Condition for Determination of Zinc Bacitracin, Polymyxin B, Oxytetracycline and Sulfacetamide in Animal Feed by Micellar Electrokinetic Capillary Chromatography}

\begin{tabular}{|r|l|}
\hline Journal: & Food Additives and Contaminants \\
\hline Manuscript ID: & TFAC-2006-345.R1 \\
\hline Manuscript Type: & Original Research Paper \\
\hline Author: & 14-Jul-2007 \\
\hline Complete List of Authors: & $\begin{array}{l}\text { Injac, Rade; Faculty of Pharmacy, Pharmaceutical biology } \\
\text { Mlinaric, Ales; Faculty of Pharmacy, Pharmaceutical Biology } \\
\text { Djordjevic-Milic, Vukosava; Faculty of Medicine, Department of } \\
\text { Pharmacy } \\
\text { Karljikovic-Rajic, Katarina; Faculty of Pharmacy, Institute of } \\
\text { Analytical Chemistry } \\
\text { Strukelj, Borut; Faculty of Pharmacy, Pharmaceutical Biology }\end{array}$ \\
\hline Methods/Techniques: & Chromatography - electrophoresis \\
\hline Additives/Contaminants: & $\begin{array}{l}\text { Additives general, Veterinary drug residues - antibiotics, Veterinary } \\
\text { drug residues - oxytetracyclin }\end{array}$ \\
\hline Food Types: & Animal feed, Animal feedingstuffs \\
\hline & \\
\hline
\end{tabular}

\section{SCHOLARONE \\ Manuscripts}


Optimal Condition for Determination of Zinc Bacitracin, Polymyxin B, Oxytetracycline and Sulfacetamide in Animal Feed by Micellar Electrokinetic Capillary Chromatography

Rade Injac ${ }^{*}$, Ales Mlinaric ${ }^{1}$, Vukosava Djorjevic-Milic ${ }^{2}$, Katarina KarljikovicRajic $^{3}$, Borut Strukelj

1 Faculty of Pharmacy, Institute of Pharmaceutical Biology, University of Ljubljana, Askerceva 7, 1000 Ljubljana, Slovenia

${ }^{2}$ Faculty of Medicine, Department of Pharmacy, University of Novi Sad, Hajduk Veljka 3, 21000 Novi Sad, Serbia

${ }^{3}$ Faculty of Pharmacy, Institute of Analytical Chemistry, University of Belgrade, Vojvode Stepe 450, 11221 Belgrade, Serbia 


\begin{abstract}
A separation of zinc bacitracin, polymyxin B, oxytetracycline and sulfacetamide in animal feedstuffs by micellar electrokinetic capillary chromatography (MEKC) was developed. The running buffer was $20 \mathrm{mmol} \mathrm{\textrm {L } ^ { - 1 }}$ borate $20 \mathrm{mmol} \mathrm{L}^{-1}$ phosphate, $\mathrm{pH} 8.4$, containing $20 \mathrm{mmol} \mathrm{L}^{-1}$ sodium dodecylsulphate and $10 \%$ (v/v) methanol. MEKC was performed at $25^{\circ} \mathrm{C}$, the applied voltage was $25 \mathrm{kV}$ and running pressure of 10 mbar was applied. Simultaneous UV detection for all analytes was at $215 \mathrm{~nm}$. The method was validated for specificity, accuracy, linearity, precision and robustness. It was shown to be specific, accurate (recoveries were $99.7 \pm 0.3,99.9 \pm 0.9,99.8 \pm 1.0$ and $99.5 \pm 0.4$, respectively for oxytetracycline, sulfacetamide, polymyxin B and zinc bacitracin spiked samples of feed for cow, pigs, chicken and cattle), linear over the tested range (correlation coefficients $\geq 0.9987$ ), and precise (RSDs below $1.8 \%$ for each analyte). The method was applied to determine zinc bacitracin, polymyxin $B$, oxytetracycline and sulfacetamide as additives in animal feed.
\end{abstract}

KEYWORDS: Animal feed additives, Zn bacitracin, oxytetracycline, polymyxin B, sulfacetamide, micellar electrokinetic capillary chromatography (MECK) 


\section{INTRODUCTION}

Feed additives are intended to improve feed quality, nutritional aspects, animal health and animal performance. According to Regulation (EC) No. 1831/2003 (European Union, 2003) there are a wide range of substances considered as feed additives and classified as technological, organoleptic, nutritional and zootechnical (i.e. increasing animal production or performance).

Antibiotics have been used in the rearing of food-producing animals in livestock farm industries as active disease treatment agents for prophylactics and in cases of pulmonary, urinary and digestive infections as feed additives. The use of these drugs to control and treat animal disease and to promote fast, more efficient growth of livestock is a common practice. Improper use, as well as the systematic administration of such additives at sub-therapeutic doses can lead to the development of antibiotic-resistant bacteria that can be transferred to humans (Witte, 1998; Smith and Coast, 2002). Since 1999, the European Union has forbidden the use of those antibiotics as additive in animal feed (Molterer, 1998), but they are still in use in non EU countries.

Recently, Serratosa et al., (Serratosa et al., 2006) published an overview of the presence of residues from veterinary medicinal products, growth-promoting agents and performance enhancers in food-producing animals, as a result of legally or illegally administration of these substances, as well as the current 
situation in EU and practical challenges for uncovering illegal uses and prevention public health risks.

In order to carry out an efficient official controls of the possible illegal use of these drugs in feeding stuffs, reliable methods of analysis need to be available with efficient separation and high sensitivity. Oka et al., (2000) reviewed the literature for the assay of tetracycline antibiotics in food, among which oxytetracycline, tetracycline, chlortetracycline and doxycycline are commonly applied to food-producing animals. They have summarized the application of thin-layer chromatography, capillary electrophoresis, and HPLC for the separation and detection, as well as extraction and clean up procedures for real samples.

Capillary electrophoresis (CE) has become a very useful method for pharmaceutical analysis and in comparison with HPLC has many advantages such as: high resolution, speed, the exceptionally small sample volume required and low content of organic solvents in running buffer and short run time for the separation. Oka et al., (2000) indicated that CE had less applications in the analysis of drugs in food due to low sample injection volume, and on the other hand authors pointed out that due to properties of tetracycline's these bind with silanol groups in the stationary phase interfere with the establishment of a simple analytical method. 
Recently, Kowalski et al., (2003) proposed a CE method with UV detection for eight of the most frequently used antibiotics (among those was doxycycline) with detection limit of drug residue in tissues at level below $20 \mu \mathrm{g} / \mathrm{kg}$. One of the commonly used CE modes is micellar electrokinetic capillary chromatography (MEKC), which is efficient for the separation of both ionic and neutral analytes. Success of the separation is based mainly on appropriate selection of the surfactant. The results of MECK application for $\mathrm{Zn}$ Bacitracin and nystatin separation and assay in animal feed, recently developed in our laboratories (Injac et al., 2006) demonstrated that this technique could be the alternative to HPLC method, but also the simple extraction procedure was proposed. For zinc bacitracin in animal feed Capitán-Vallvey et al. (2001 and 2002) proposed HPLC methods with UV and fluorescence detection, but with difficult extraction procedures using LLE as well as SPE techniques.

In the continuation of our research studies we selected, beside $\mathrm{Zn}$ Bacitracin ( $\mathrm{Zn}$ BAC), oxytetracycline (OXY), polymyxin B (POL B) and sulfacetamide (SUL) to investigate the separation applying MECK with the similar extraction procedure described in previously published paper (Injac et al., 2006). OXY, SUL, Zn BAC and POL B have been determined in pharmaceutical formulations by CZE and MEKC (Gallego and Arroyo, 2002; Gallego and Arroyo, 2003a; Gallego and Arroyo, 2003b; Gallego and Arroyo, 2003c; Gallego and Arroyo, 2003d; Mamani et al., 2006; Nozal et al., 2004). Kang et al. (Kang et al., 2001) have used MEKC to separate bacitracin components, with Brij 35 and PAPS as surfactants. 
Counter-current chromatography and high-performance liquid chromatography were used for the separation of Zn-bacitracin (Oka et al., 1998; Capitan-Vallvey et al., 2002; Sin et al., 2005). Tetracyclines and sulfonamides were analysed by liquid chromatography-electrospray ionization tandem mass spectrometry, as well as with HPLC-UV, LC/MS/MS in wastewaters, pharmaceuticals and food (Yang et al., 2005; Zhao et al., 2004; Mandens et al., 2004; Rao et al., 1999).

Zn BAC interferes with bacterial cell wall synthesis by bloking the function of the lipid carrier molecule that transfers cell wall subunits across the cell membrane. It is active against many Gram-positive bacteria. Acquried bacterial resistance to bacitracin rarely occurs (Martindale, 2005). Oxytetracycline is bacteriostatic antibiotic with a wide spectrum of activity and has been used in the treatment of a large number of infections caused by susceptible organisms. Polymyxin B and the other polymyxin antibacterials act primarily by binding to membrane phospholipids and disrupting the bacterial cytoplasmic membrane. The use of sulfacetamide and other sulfonamides has been limited by the increasing incidence of resistant organisms (Wang et al., 2006). Their main use has been in the treatment of acute, uncomplicated urinary-tract infections, particularly those caused by Escherichia coli (Martindale, 2005).

Selected analytes, OXY, SUL, Zn-BAC and POL used as additives in animal feed at levels $100-200 \mathrm{mg} \mathrm{kg}^{-1}, 100 \mathrm{mg} \mathrm{kg}^{-1}, 50-250 \mathrm{mg} \mathrm{kg}^{-1}$ and $50-150 \mathrm{mg} \mathrm{kg}^{-1}$, 
respectively (Swine antibiotics and feed additives, 2006; Frost \& Sullivan, 2005; National Department for Veterinary Science, 2006).

The aim of this paper was to establish the optimal conditions for MECK separation and assay using the model mixture of OXY, Zn BAC and POL B in spiked feedstuff samples, antibiotics belonging to different cases of antibiotics, in combination with SUL as these can be found as feed additives. The model mixture is also of interest since, polymyxins have been reported to demonstrate antimicrobial synergy with a variety of other drugs, including chloramphenicol, tetracycline, and the sulfonamides and trimethoprim (Martindale, 2005), and as such the prophylactics in food could be covered with these representative drugs.

\section{MATERIALS AND METHODS}

\section{Apparatus}

The HP ${ }^{3 D}$ Capillary Electrophoresis system (Hewlett Packard, Waldbronn, Germany) with a diode-array detector, controlled by HP ChemStation software, was used to perform MEKC. Compounds were separated on a $48 \mathrm{~cm}(40 \mathrm{~cm}$ to the detector) x $50 \mu \mathrm{m}$ i.d. fused silica capillary (with bubble cell, $150 \mu \mathrm{m}$ ) (Agilent, Waldbronn, Germany).

A Crison MicropH $2002 \mathrm{pH}$ meter (Barcelona, Spain) was used for $\mathrm{pH}$ measurement.

\section{Reagents and solutions}


All solvents and reagents were of analytical grade unless indicated otherwise. Samples solutions were prepared with deionized water (Milli-Q-quality). Sulfacetamide sodium was obtained from Vetprom (Belgrade, Serbia) and Znbacitracin from Sigma (Deisenhofen, Germany). The quality of the both complied with BP requirements. Oxytetracycline hydrochloride and polymyxin B sulphate were obtained from Sigma (Deisenhofen, Germany) and Fluka (Buchs, Switzerland), respectively (USP quality).

Animal diet and feedstuff mixtures for cow K-19 (protein min $19 \%$, crude fat max $15 \%$, ash max $15 \%$, crude fiber max $10 \%$, calcium $0.8 \%$, phosphorus $0.45 \%$, sodium $0.25 \%$, moisture max $13.5 \%$, vitamins $A, D_{3}$, E, zinc, manganese, selenium, cobalt, copper, iron and iodine), young cattle TL-TIP (protein min $14 \%$, ash max $10 \%$, crude fiber max $12 \%$, moisture max $13.5 \%$, vitamins $A, D_{3}, E$, zinc, manganese, selenium, cobalt, copper and magnesium), pigs from 25 to 60 kg BEK-1 (protein $17 \%$, ash max $8 \%$, crude fiber max $7 \%$, moisture max 13.5 $\%$, vitamins $\mathrm{A}, \mathrm{D}_{3}, \mathrm{E}, \mathrm{B}$-complex, zinc, selenium, manganese, iodine, cobalt, copper, iron and antioxidants Sanox), chicken feed NSK-1 (protein min $15 \%$, moisture max $13.5 \%$, crude fiber max $8 \%$, ash max $12 \%$, vitamins $A, D_{3}, E, K_{3}$, B-complex, zinc, selenium, manganese, iodine, cobalt, copper, iron, carophyll red and antioxidants Sanox), and minerals and vitamins for cattle BOVISAL (calcium $16 \%$, phosphorus $11 \%$, sodium $10 \%$, magnesium $0.6 \%$, moisture max $7 \%$, vitamins $A, D_{3}, E$, zinc, manganese, selenium, iodine, cobalt and copper), were manufactured by JATA EMONA (Ljubljana, Slovenia). 
Buffer solutions were prepared by dissolving the appropriate amount of $\mathrm{NaH}_{2} \mathrm{PO}_{4}$ (20 mmol L-1) and $\mathrm{Na}_{2} \mathrm{~B}_{4} \mathrm{O}_{7}\left(20 \mathrm{mmol} \mathrm{L}^{-1}\right)$ in deionized water and the $\mathrm{pH}$ was adjusted to 8.4 with $\mathrm{HCl}$. $\mathrm{Na}_{2} \mathrm{~B}_{4} \mathrm{O}_{7} \times 10 \mathrm{H}_{2} \mathrm{O}$ was p.a. from Kemika (Zagreb, Croatia) and $\mathrm{NaH}_{2} \mathrm{PO}_{4} \times \mathrm{H}_{2} \mathrm{O}$ was p.a. from J.T. Baker Inc. (Phillipsburg, USA). Sodium dodecylsulphate (SDS) was from Riedel Line AG (Seelze,Germany).

The background electrolyte (BGE) was $20 \mathrm{mmol} \mathrm{L}^{-1}$ borate $+20 \mathrm{mmol} \mathrm{L}^{-1}$ phosphate buffer, $\mathrm{pH} 8.4$, containing $20 \mathrm{mmol} \mathrm{L}^{-1}$ SDS and $10 \%(\mathrm{v} / \mathrm{v})$ methanol.

\section{Preparation of standard stock solutions}

Stock solutions of antibiotics were prepared by weighing $50 \mathrm{mg}$ of the drugs and dissolving in $50 \mathrm{~mL}$ methanol - deionized water $(1: 1 ; \mathrm{v} / \mathrm{v})$. The stock solutions were diluted with running buffer to obtain the concentration ranges required (linearity was check in range of $0.1-100 \mathrm{mg} \mathrm{kg}^{-1}$ for each drug).

\section{Sample preparation and extraction}

Spiked animal feed were prepared by grinding $500 \mathrm{~g}$ of feedstuff and adding 50 $\mathrm{mg}$ of each of the antibacterial. Blank feed or spiked feed with added antibiotics, were weighed $(100 \mathrm{~g})$ and extracted with methanol $(5 \times 20 \mathrm{~mL})$, first by shaking, then in an ultrasonic bath for $15 \mathrm{~min}$. The extracts were combined, filtered $(0.22$ $\mu \mathrm{m})$, transferred to $100 \mathrm{~mL}$ volumetric flask, and made up with methanol. Different known volumes were placed in $1.5 \mathrm{~mL}$ calibrated vials and diluted to volume with running buffer. 


\section{Operating conditions}

The capillary was conditioned prior to its first use by flushing with $0.1 \mathrm{~mol} \mathrm{~L}^{-1}$ $\mathrm{NaOH}$ for 20 min and then with water for $10 \mathrm{~min}$. The capillary was conditioned, in the optimized method, at the beginning of each day with methanol under high pressure for $3 \mathrm{~min}$, than rinsed for $2 \mathrm{~min}$ with $0.1 \mathrm{~mol} \mathrm{~L}^{-1} \mathrm{NaOH}$ and $3 \mathrm{~min}$ with background electrolyte. This was followed by hydrodynamic sample injection at 600 mbars. Separations were performed at $25 \mathrm{kV}$ and $25^{\circ} \mathrm{C}$ (under applied pressure of $10 \mathrm{mbar}$ ) in $12 \mathrm{~min}$; under these conditions the current was 97-98 $\mu \mathrm{A}$. UV detection was at $215 \mathrm{~nm}$.

\section{RESULTS AND DISCUSSION \\ Preliminary studies}

Preliminary investigations of $\mathrm{Zn}-\mathrm{BAC}, \mathrm{SUL}, \mathrm{OXY}$ and POL B were carried out, to optimize the separation. MEKC methods were published for the determination of hydrocortisone and its most important associated compounds (including Zn-BAC, POL B and OXY) in topical pharmaceutical preparations (Gallego and Arroyo, 2002; Gallego and Arroyo, 2003c) SUL were determined in pharmaceuticals by MEKC with others associated compounds (Gallego and Arroyo, 2003a). Some modifications of the SDS concentration, organic modifier and applied pressure were assessed to obtain a shorter run time and better resolutions in separation of of all analytes from animal feed. 
The published literature (Gallego and Arroyo, 2002; Gallego and Arroyo, 2003a) pointed out the effect of $\mathrm{pH}$ values $(6-11)$ of phosphate-borate (1:1) buffer, buffer component concentrations (10 to $60 \mathrm{mmol} \mathrm{L}^{-1}$ ) and effect of organic modifier (methanol, acetonitrile; $3-12 \%$ ). In our research the presence of $10 \%$ methanol in the electrolyte resulted, in well resolved peaks and the shoulders disappeared. The results demonstrated the separation is better when the $\mathrm{pH}$ is between 8 and 9. A $40 \mathrm{mmol} \mathrm{L}-1\left(20 \mathrm{mmol} \mathrm{L}^{-1}\right.$ borate $/ 20 \mathrm{mmol} \mathrm{L}^{-1}$ phosphate buffer) concentration was considered suitable for its good resolution and peak shape. Higher concentration of buffer resulted in peak broadening.

Running voltages effects in the range $5-30 \mathrm{kV}$ were tested using a background electrolyte of $20 \mathrm{mmol} \mathrm{L}^{-1}$ borate $/ 20 \mathrm{mmol} \mathrm{L}^{-1}$ phosphate buffer, $\mathrm{pH} 8.4$, containing 10-80 mmol L-1 sodium dodecylsulphate (SDS) and 10\% methanol, without running pressure, at $25^{\circ} \mathrm{C}$. The best results were at $25 \mathrm{kV}$, and an acceptable level of baseline noise was achieved by performing experiments at $25^{\circ} \mathrm{C}$.

The influence of SDS in the electrolyte on the migration time (without running pressure) is very significant. The results show that the SDS concentration dramatically affects the migration time of the $\mathrm{Zn}-\mathrm{BAC}$ and POL $\mathrm{B}$, but not that of SUL and OXY. A concentration of $70 \mathrm{mmol} \mathrm{L}^{-1}$ was selected for the experiment as to give the best resolution, but without a short analysis time (20 min) and without good symmetry and widths of Zn-BAC and POL B peaks. 
Running pressure was tested in the range 5-30 mbar, using the above experimental conditions. Migration times were decreased with increasing running pressure, and the value of 10 mbar was selected as optimum. It gives the best resolution and symmetric peaks in all cases, and also the analysis time is shorter. Under such experimental conditions the concentration of $20 \mathrm{mmol} \mathrm{L}^{-1}$ SDS was selected as the most advantageous. It gave the best separation without broadened and deformed peaks, and acceptable resolution for Zn-BAC and POL B (Figure 1).

The best results were with applying pressure of 10 mbar at $25 \mathrm{kV}$. UV detection was at 215 and $254 \mathrm{~nm}$ for $\mathrm{Zn}$-BAC, SUL and OXY, 205 and at $215 \mathrm{~nm}$ for POL $\mathrm{B}$, for simultaneous detection $215 \mathrm{~nm}$ was selected. The electropherograms obtained in the separation under selected conditions are presented in Figure 2. It is remarkable that all peaks have good resolutions in a run time of $12 \min$ (OXY 3.1; SUL 3.7; POL B 9.3; Zn-BAC 10.6). The conditions of MECK with SDS was exceptionally suitable for OXY, since it is eluted as the first peak without any interferences, confirming that this technique could be more efficient in comparison to HPLC, since Oka et al. (2000) pointed out that EDTA and oxalic acid should be used during each analytical step (extraction, clean up and HPLC separation). Our recently published paper (Injac et al. 2007) denoted sufficient difference in migration time for two tetracycline antibiotic OXY and doxycycline.

\section{Validation of the method}


The characteristics and the procedures used for validation were those described in USP 24 (USP 24, 2000), the International Conference of Harmonization (ICH) Guidelines (ICH Q2A, 1995; ICH Q2B, 1997) and other literature (Heyden et al., 1999; Shabin, 2003; Brown et al., 2001; Toro et al., 2004; Altria and Chanter, 1993; Injac et al., 2007).

\section{Selectivity}

The selectivity of the method was investigated by observing interfering peaks from matrix present in the feedstuffs. Five different feedstuff mixtures were tested for the interferences. There was no interference in MEKC results by the feed's ingredients in any of the tested mixtures, which indicates that the method is selective.

\section{Linearity}

The linearity of the assay was determined by analysis of a series of standards at five different concentrations in range of 0.1 to $100 \mathrm{mg} \mathrm{kg}^{-1}$ for each compound. The linearity of calibration curves (peak area vs. concentration) for OXY, SUL, POL B and Zn-BAC over the concentration ranges of $6.5-77.2 \mathrm{mg} \mathrm{kg}^{-1}$ for $\mathrm{OXY}$, $0.3-84.5 \mathrm{mg} \mathrm{kg}^{-1}$ for SUL, $18.5-85.0 \mathrm{mg} \mathrm{kg}^{-1}$ for POL B and $12.1-62.4 \mathrm{mg} \mathrm{kg}^{-}$ ${ }^{1}$ for Zn-BAC gave correlation coefficients of $0.9994,0.9997,0.9987$ and 0.9991 , respectively.

\section{Limit of detection (LOD) and limit of quantification (LOQ)}


LODs and LOQs were estimated by the baseline noise method. Baseline noise was evaluated by recording the detector response over a period of ten times the peak width. LOD and LOQ, respectively, were defined as the analyte concentrations resulting in peaks of height three and ten times the baseline noise level ((ICH Q2A, 1995; ICH Q2B, 1997; Heyden et al., 2001). Thus, LODs/LOQs are 1.6/6.2, 0.1/0.3, 6.0/17.5 and 3.7/12.3 $\mathrm{mg} \mathrm{kg}^{-1}$ for OXY, SUL, POL B and ZnBAC, respectively.

\section{Accuracy}

The accuracy of the method was determined by analyzing a solution of known concentration (working standard solution - spiked feed samples with standards) and comparing the measured and known values. Fifteen determinations were carried out for five concentration levels. The mean recovery was $99.7 \pm 0.3,99.9$ $\pm 0.9,99.81 \pm 1.0$ and $99.5 \pm 0.4$ for OXY, SUL, POL B and Zn-BAC, respectively, proving a good accuracy of the method.

\section{Precision}

Precision can be measured as repeatability, reproducibility, and intermediate precision. In this work only repeatability and intermediate precision were studied.

\section{Repeatability}

A repeatability test was performed to determine intra-day variation in corrected areas and migration times. Working solutions of concentrations 20, 40 and $60 \mathrm{mg}$ $\mathrm{L}^{-1}$ (relative to 20, 40 and $60 \mathrm{mg} \mathrm{kg}^{-1}$ ) were analyzed $(n=6)$. The RSD values for 
migration times $(0.29 \%$ for OXY, $0.13 \%$ for SUL, $0.94 \%$ for POL B and $0.82 \%$ for Zn-BAC) and for peak areas (0.92-1.76 \% OXY, 0.57-0.77 \% SUL, 1.12-1.53 $\%$ POL $B$ and $0.85-1.72 \% \mathrm{Zn}-\mathrm{BAC}$ ) indicate that the repeatability of the method is acceptable.

\section{Intermediate Precision}

Intermediate precision was evaluated over three days by performing working solutions of concentrations $20-50 \mathrm{mg} \mathrm{L}^{-1}$ (relative to $20-50 \mathrm{mg} \mathrm{kg}^{-1}$ ). These were injected on each of three days under the same conditions and the results were used for the repeatability study. When stored in the dark refrigerated, the recovery ranged from 100.2 to $99.1 \%$ over three days. The RSD values $(0.12-$ $0.34 \%$ for OXY, $0.09-0.25 \%$ for SUL, $0.39-0.83$ for POL B and $0.42-0.81 \%$ for $\mathrm{Zn}-\mathrm{BC})$ indicate that the intermediate precision is acceptable. When they were stored at room temperature in sunlight, decreasing recovery values from 100.15 to $94.81 \%$ for $\mathrm{Zn}-\mathrm{BAC}$, from 100.40 to $95.03 \%$ for POL B and from 100.01 to $92.98 \%$ for OXY were observed for the standards in BGE.

\section{Robustness}

The optimum MEKC conditions set for this method have been slightly modified in order to evaluate the robustness. The effects of different concentrations of SDS $\left(20 \pm 1 \mathrm{mmol} \mathrm{L}^{-1}\right)$ and organic modifier (10 $\pm 0.5 \%$ methanol) in the mobile phase, as well as the effects of buffer $\mathrm{pH}(8.4 \pm 0.06)$, capillary temperature $(25 \pm$ $\left.5^{\circ} \mathrm{C}\right)$, applied pressure (10 $\left.\pm 1 \mathrm{mbar}\right)$, running voltage $(25 \pm 1 \mathrm{kV})$ and detection wavelength $( \pm 3 \mathrm{~nm})$, and were determined. The design applied was the 
fractional factorial design (Heyden et al., 2001). No significant variations in accuracy, specificity and precision were found over the tested ranges, which indicated that the method conditions are robust.

\section{Stability of antibiotics}

The stability of OXY, SUL, POL B and $\mathrm{Zn}-\mathrm{BAC}$ in acidic $(\mathrm{pH}<5)$ and basic $(\mathrm{pH}>$ 10) solutions was checked in test samples at room temperature for 24 and $48 \mathrm{~h}$ and the recoveries were $98.2 \pm 2.3 \%$ at $24 \mathrm{~h}$ and $95.8 \pm 3.8 \%$ at $48 \mathrm{~h}$. The stability in the BGE was also checked at $24 \mathrm{~h}$. Recoveries of each compounds were $\geq 99.3 \%$. It was indicating good stability.

\section{Application}

The present method was tested by determining OXY, SUL, POL B and Zn-BAC in animal feedstuffs. When analyzing spiked commercial products, the amounts and recoveries obtained were determined by comparing the results with a standard solution containing the same concentration as expected in the spiked commercial products. The results presented in Table I show good agreement between the claimed and found values. Recovery values also confirmed that, due to the sufficient solubility of investigated compounds, extraction procedure was efficient.

According to $L O Q$ values for each analyte, the minimum quantifiable amounts with the proposed method are $6.2,0.3,17.5$ and $12.3 \mathrm{mg} \mathrm{kg}^{-1}(\mathrm{ppm})$ of OXY, 
SUL, POL B and Zn-BAC, respectively in feed. The sensitivity of the proposed method is acceptable in relation to the efficiency levels of OXY, SUL, POL B and $\mathrm{Zn-BAC}$ as additives and can be utilized for routine control of animal feedstuffs. The obtained results are in correlation that CE is already an official method in USP will also be valuable method as the alternative to HPLC (S. Görög, 2007) and the precision of MECK (Injac et al., 2007) confirmed the applicability in routine quality control.

The advantage of proposed method over the HPLC and TLC methods described in literature for analysis OXY, SUL, POL B and Zn-BAC in different samples is its lower running costs and higher environmental friendliness. In the proposed method, 20-30 analyses with MEKC require $2 \mathrm{~mL}$ of phosphate/borate buffer containing SDS and $10 \%(\mathrm{v} / \mathrm{v})$ methanol, while 20 analyses by HPLC require 300 to $1000 \mathrm{~mL}$ of mobile phase with different proportion of most commonly used organic solvent (methanol, acetonitrile, acetone, THF). The advantage of LC (MS; MS/MS) methods over MECK is evident for the analysis of residues in samples of different tissues (Bogialli et al., 2003).

\section{CONCLUSION}

The MEKC method presented here is a useful technique for rapid separation (within 12 min) of zinc bacitracin, polymixin B, oxytetracycline and sulfacetamide at low concentration of surfactant (SDS $20 \mathrm{mmol} \mathrm{L}^{-1}$ ) and $\mathrm{pH} 8.4$ (phosphateborate buffer). A pressure of 10 mbar was applied and it gives the best resolution 
and symmetric peaks in all cases, special for POL B and Zn-BAC. This system was also applied successfully to their identification and assay in animal feedstuff, with different matrixes, spiked with zinc bacitracin, polymixin B, oxytetracycline and sulfacetamide.

\section{Acknowledgment}

This work was financed in part by the Ministry of Science and Environment protection, Belgrade, Serbia, as part of Project no. 142072.

\section{REFERENCES}

Altria KD, Chanter YL. 1993. Validation of a capillary electrophoresis method for the determination of a quinolone antibiotic and its related impurities. Journal of Chromatography 652: 459-463.

Bogialli S, Curini R, Di Corcia A, Nazzari M, Samperi R, 2003. A Liquid Chromatography-Mass Spectrometry Assay for Analyzing Sulfonamide Antibacterials in Cattle and Fish Muscle Tissues. Analytical Chemistry 75: 17981804.

Brown R, Caphart M, Faustino P, Frankewich R, Gibbs J, Leutzinger E, Lunn G, $\mathrm{Ng}$ L, Ragagopalan R, Chiu Y, Sheinin E. 2001. Analytical Procedures and Method Validation: Highlights of the FDA's Draft Guidance. LC-GC 19: 74-79. 
Capitán-Vallvey LF, Novas N, Titos A, R. Checa R. 2001. Determination of the Antibiotic Zinc Bacitracin in Animal Food by High-Performance liquid Chromatography with Ultraviolet Detection. Chromatographia 54: 15-20.

\begin{abstract}
Capitan-Vallvey LF, Titos A, Checa R, Navas N. 2002. High-performance liquid chromatography determination of $\mathrm{Zn}$-bacitracin in animal feed by post-column derivatization and fluorescence detection. Journal of Chromatography A 943: 227-234.
\end{abstract}

European Union. 2003. Regulation (EC) No. 1831/2003 of the European Parliament and of the Council of 22 September 2003 on additives for use in animal nutrition. Official Journal of the European Union L 268: 29-43.

Frost \& Sullivan. The 2006 Antibiotic Growth Promoter Ban - What Impact will it have on the Animal Feed Industry [internet]. Available from: http://www.frost.com/prod/servlet/market-insight-top.pag?docid=53623667. Accessed: 24 Nov 2005.

Gallego JML, Arroyo JP. 2002. Micellar Electrokinetic Capillary Chromatography as an Alternative Method for Determination of Hydrocortisone and its Most Important Associated Compounds in Local Pharmaceutical Preparations. Chromatographia 56: 455-462. 
Gallego JML, Arroyo JP. 2003a. Determination of prednisolone and the most important associated compounds in ocular and cutaneous pharmaceutical preparations by micellar electrokinetic capillary chromatography. Journal of Chromatography B 784: 39-47.

Gallego JML, Arroyo JP. 2003b. Optimized Method for the Determination of Prednisolone, Zn-Bacitracin and Phenylephrine in Local Pharmaceutical Preparations by Micellar Electrokinetic Capillary Chromatography. Chromatographia 58: 277-281.

Gallego JML, Arroyo JP. 2003c. Determination of hydrocortisone, polymyxin B and $\mathrm{Zn}$-bacitracin in pharmaceutical preparations by micellar electrokinetic chromatography. Analytical and Bioanalytical Chemistry 375: 617-622.

Gallego JML, Arroyo JP. 2003d. Determination of Hydrocortisone and Associated Compounds in Pharmaceutical Preparations by Micellar Electrokinetic Chromatography. Journal of Liquid Chromatography and Related Technologies 26: 1011-1025.

Görög S. 2007. The changing face of pharmaceutical analysis. Trends in Analytical Chemistry 26: 12-17. 
Heyden YV, Jimidar M, Hund E, Niemeijer N, Peeters R, Smeyers-Verbeke J, Massart DL, Hoogmartens J. 1999. Determination of system suitability limits with a robustness test. Journal of Chromatography A 845: 145-154.

Heyden YV, Nijhuis A, Smeyers-Verbeke J, Vandeginste BGM, Massart DL. 2001. Guidance for robustness/ruggedness tests in method validation. Journal of Pharmaceutical and Biomedical Analysis 24: 723-753.

Injac R, Kac J, Mlinaric A, Karljikovic-Rajic K. 2006. Micellar electrokinetic capillary chromatography determination of zinc bacitracin and nystatin in animal feed. Journal of Seperation Science 29: 1288-1293.

Injac R, Kocevar N, Kreft S. 2007. Precision of micellar electrokinetic capillary chromatography in the determination of seven antibiotics in pharmaceuticals and feedstuffs. Analytica Chimica Acta 594(1): 119-227.

International Conference on Harmonization, guideline Q2A: Text on validation of analytical procedures. 1995. Federal Register 60: 11260.

International Conference on Harmonization, guideline Q2B: Validation of analytical procedures: methodology. 1997. Federal Register 62: 27463-27467. 
Kang JW, De Reymaeker G, Van Schepdael A, Orwa J, Roets E, Hoogmartens J. 2001. Analysis of bacitracin by micellar electrokinetic capillary chromatography with mixed micelle in acidic solution. Electrophoresis 22: 1356-1362.

Kowalski P, Olędzka I, Lamparczyk H. 2003. Capillary electrophoresis in analysis of veterinary drugs. Journal of Pharmaceutical and Biomedical Analysis 32: 937947.

Mamani MCV, Farfán JA, Reyes FGR, Rath S. 2006. Simultaneous determination of tetracyclines in pharmaceuticals by CZE using experimental design. Talanta 70: 236-243.

Mandens KE, Zhang GF, Lambert WE. 2004. Quantitative analysis of twelve sulfonamides in honey after acidic hydrolysis by high-performance liquid chromatography with post-column derivatization and fluorescence detection. Journal of Chromatography A 1047: 85-92.

Martindale. 2005. The complete drug reference. 34th edition. Sweetman SC (ed.). Pharmaceutical Press. UK, pp. 161, 241, 245 and 257.

Molterer W. 1998. Official Journal of European Communities: Legis. L351/4-8. 
National Department for Veterinary Science. Government of the Republic of Slovenia. Feed Additives [internet] Available from: http://www.vurs.gov.si/ Accessed 2006 May 10.

Nozal L, Arce L, Simonet BM, Rios A, Valcarcel M. 2004. Rapid determination of trace levels of tetracyclines in surface water using a continuous flow manifold coupled to a capillary electrophoresis system. Analytical Chimica Acta 517: 8994.

Oka H, Harada K-I, Ito Y, Ito Y. 1998. Separation of antibiotics by counter-current chromatography. Journal of Chromatography A 812: 35-52.

Oka H, Ito Y., Matsumoto H. 2000. Chromatographic analysis of tetracycline antibiotics in foods. Journal of Chromatography A 882: 109-133.

Rao RM, Rao YM, Shah AH. 1999. A reverse phase ion-pairing HPLC method for the stability monitoring of sulphacetamide ophthalmic preparations. Journal of Pharmaceutical and Biomedical Analysis 20: 717-722.

Serratosa J, Blass A, Rigau B, Mongrell B, Rigau T, Tortadès M, Tolosa E, Aguilar C, Ribó O, Balagué J. 2006. Residues from veterinary medicinal products, growth promoters and performance enhancers in food-producing 
animals: a European Union perspective, Revue scientifique et technique - Office international des epizooties 25(2): 637-653.

Shabir GA. 2003.Validation of high-performance liquid chromatography methods for pharmaceutical analysis Understending the differences and similarities between validation requirements of the US Food and Drug Administration, the US Pharmacopeia and the International Conference on Harmonization. Journal of Chromatography A 987: 57-66.

Sin DW, Ho C, Wong Y, Ho S, Ip AC. 2005. Analysis of major components of residual bacitracin and colistin in food samples by liquid chromatography tandem mass spectrometry. Analytical Chimica Acta 535: 23-31.

Smith RD, Coast J. 2002. Antimicrobial resistance: a global response. Bulletin of the World Health Organization 80: 126-133.

Swine antibiotics and feed additives [internet]. Available from: http://muextension.missouri.edu. Accessed 2006 October 7.

Toro I, Dulsat JF, Fabregas JL, Claramunt, J. 2004. Development and validation of a capillary electrophoresis method with ultraviolet detection for the determination of the related substances in a pharmaceutical compound. Journal of Chromatography A 1043: 303-315. 
United States Pharmacopoeia 24 - National Formulary 19. 2000. United States Pharmacopoeial Convention, Rockville, MD, pp. 185-186.

Wang S, Zhang HY, Wang L, Duan ZJ, Kennedy I. 2006. Analysis of sulphonamide residue in edible animal products: A review. Food Additives and Contaminants 23(4): 362-384.

Witte W. 1998. Medical consequences of antibiotic use in agriculture. Science 279: 996-997.

Yang S, Cha J, Carlson K. 2005. Simultaneous extraction and analysis of 11 tetracycline and sulphonamide antibiotics in influent and effluent domestic wastewater by solid-phase extraction and liquid chromatography-electrospray ionization tandem mass spectrometry. Journal of Chromatography A 1097: 4053.

Zhao F, Zhang X, Gan Y. 2004. Determination of tetracyclines in ovine milk by high-performance liquid chromatography with a coulometric electrode array system. Journal of Chromatography A 1055: 109-114.

\section{Figure captions (R. Injac et al.)}

Figure 1. 
Effect of SDS concentration on resolution with a applied pressure of 10 mbar. The electrolyte solution was $20 \mathrm{mmol} \mathrm{L}^{-1}$ phosphate $+20 \mathrm{mmol} \mathrm{L}^{-1}$ borate buffer, $\mathrm{pH} 8.4$, containing $10 \%$ methanol, and the temperature and voltage were $25^{\circ} \mathrm{C}$ and $25 \mathrm{kV}$, respectively.

\section{Figure 2.}

Electropherograms obtained A) $100 \mathrm{mg} \mathrm{kg}^{-1}$ of $\mathrm{Zn}-\mathrm{BAC}, \mathrm{POL} \mathrm{B}$, SUL and OXY standards, and B) $50 \mathrm{mg} \mathrm{kg}^{-1}$ of Zn-BAC, POL B, SUL and OXY from spiked animal feedstuff; under the optimized conditions, at $215 \mathrm{~nm}$. The BGE was 20 mmol L-1 phosphate $+20 \mathrm{mmol} \mathrm{L}^{-1}$ borate buffer, $\mathrm{pH} 8.4$, containing $20 \mathrm{mmol} \mathrm{L}^{-1}$ SDS and $10 \%$ methanol, the temperature and voltage were $25^{\circ} \mathrm{C}$ and $25 \mathrm{kV}$, respectively with applied pressure of 10 mbar.

\section{Table I.}

Application results for spiked feedstuff samples. 
Table I R. Injac et al.

\begin{tabular}{|c|c|c|c|c|c|c|c|c|c|}
\hline $\begin{array}{c}\text { Tested } \\
\text { Sample } \\
(n=10)\end{array}$ & $\begin{array}{c}\text { Amount } \\
\text { expected } \\
(\mathrm{mg})\end{array}$ & $\begin{array}{c}\text { OXY } \\
\text { Amount } \\
\text { found } \\
(\mathrm{mg})\end{array}$ & $\begin{array}{c}\text { OXY } \\
\text { Recovery } \\
(\%)\end{array}$ & $\begin{array}{c}\text { SUL } \\
\text { Amount } \\
\text { found } \\
(\mathrm{mg})\end{array}$ & $\begin{array}{c}\text { SUL } \\
\text { Recovery } \\
(\%)\end{array}$ & $\begin{array}{c}\text { POL B } \\
\text { Amount } \\
\text { found } \\
(\mathrm{mg})\end{array}$ & $\begin{array}{c}\text { POL B } \\
\text { Recovery } \\
(\%)\end{array}$ & $\begin{array}{c}\text { Zn-BAC } \\
\text { Amount } \\
\text { found } \\
(\mathrm{mg})\end{array}$ & $\begin{array}{c}\text { Zn-BAC } \\
\text { Recovery } \\
(\%)\end{array}$ \\
\hline K-19 & 50 & $49.9 \pm 0.1$ & 99.8 & $48.9 \pm 0.5$ & 97.8 & $48.9 \pm 0.4$ & 97.8 & $49.3 \pm 0.3$ & 98.6 \\
\hline TL-TIP & 50 & $49.9 \pm 0.2$ & 99.8 & $49.8 \pm 0.3$ & 99.6 & $48.8 \pm 0.3$ & 97.6 & $49.2 \pm 0.4$ & 98.4 \\
\hline BEK-1 & 50 & $50.0 \pm 0.1$ & 100.0 & $49.9 \pm 0.1$ & 99.8 & $49.3 \pm 0.8$ & 98.6 & $50.2 \pm 0.3$ & 100.4 \\
\hline NSK-1 & 50 & $49.8 \pm 0.1$ & 99.6 & $49.7 \pm 0.4$ & 99.4 & $49.5 \pm 0.5$ & 99.0 & $50.3 \pm 0.1$ & 100.6 \\
\hline BOVISAL & 50 & $50.1 \pm 0.3$ & 100.2 & $49.8 \pm 0.2$ & 99.6 & $49.1 \pm 0.6$ & 98.2 & $49.7 \pm 0.7$ & 99.4 \\
\hline
\end{tabular}




\section{Figure 1 R. Injac et al.}

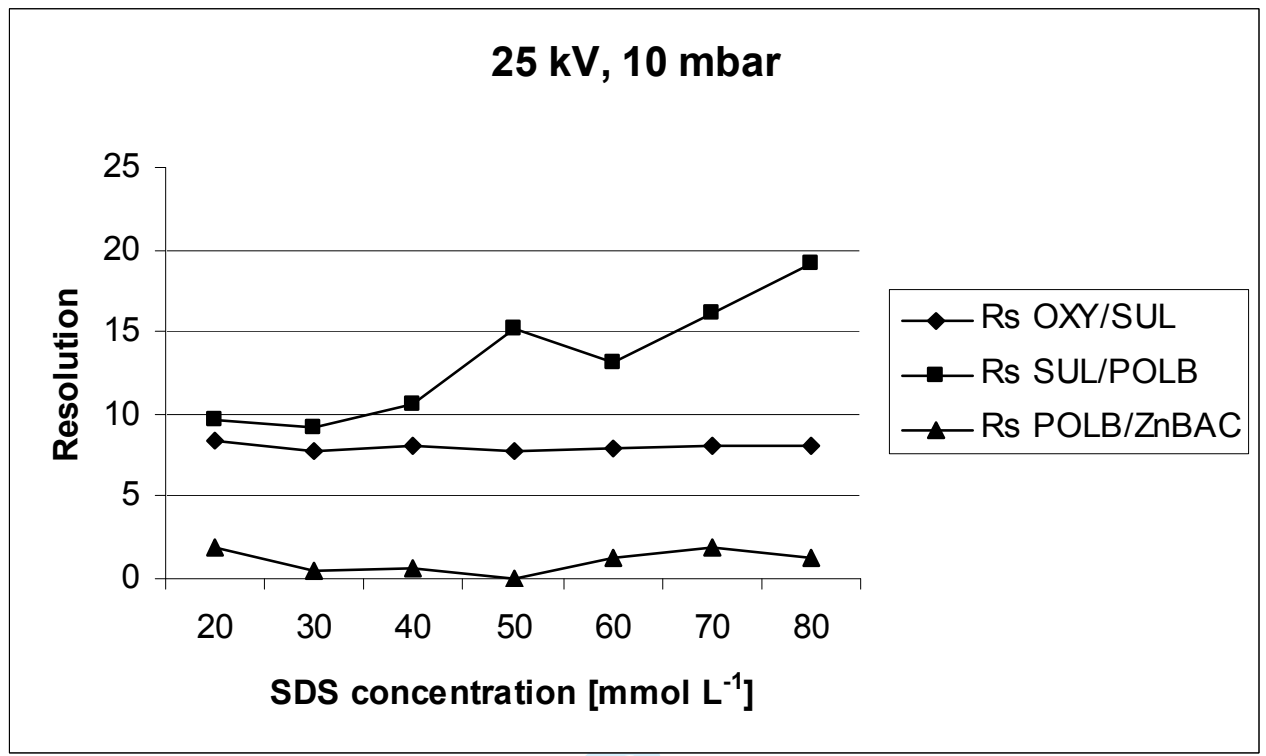

http://mc.manuscriptcentral.com/tfac Email: fac@tandf.co.uk 


\section{Figure 2A R. Injac et al.}

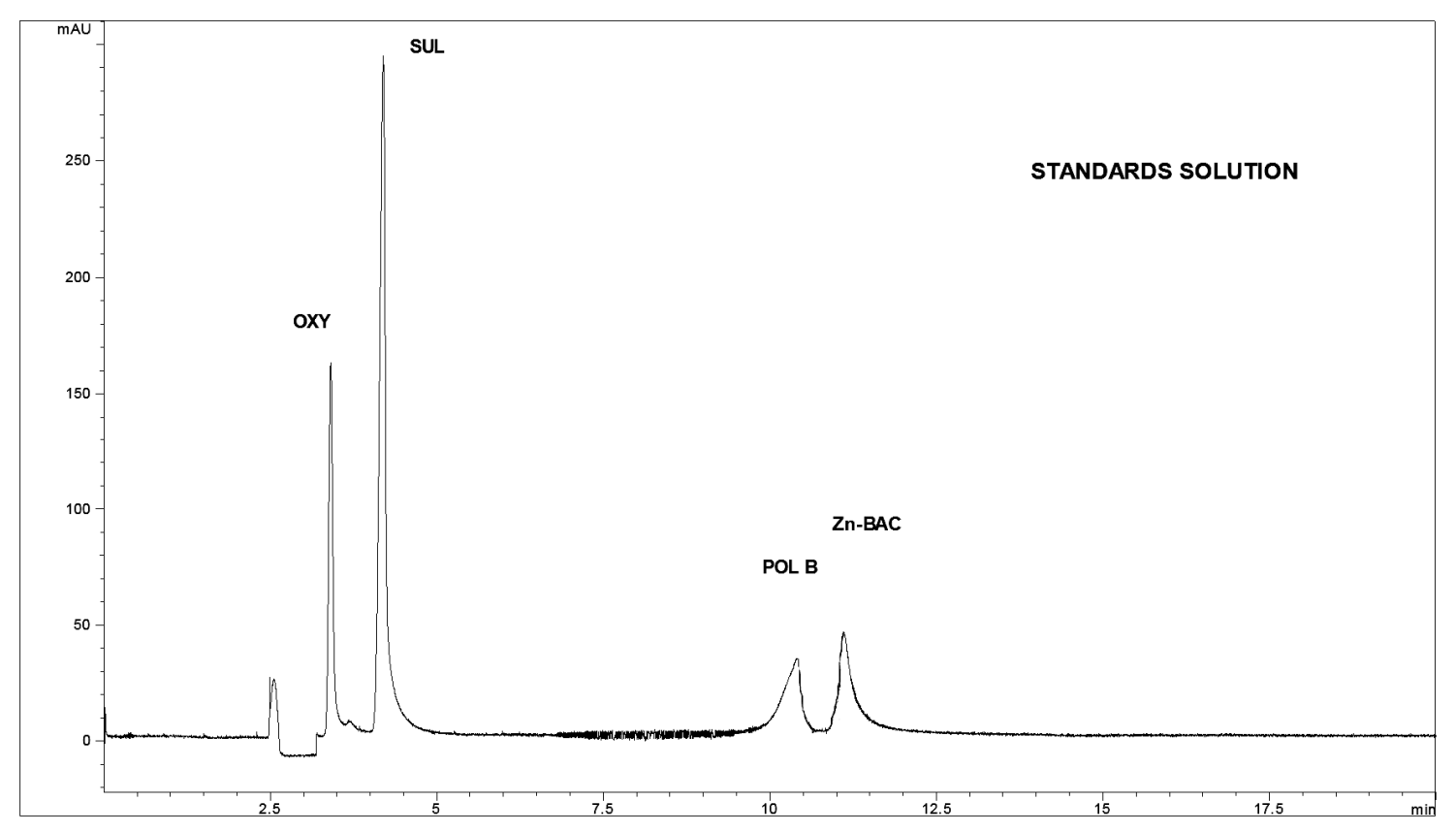

29

30

31

32

33

34

35

36

37

38

39

40

41

42

43

44

45

46

47

48

49

50

51

52

53

54

55

56

57

58

59

60

http://mc.manuscriptcentral.com/tfac Email: fac@tandf.co.uk 
Figure 2B R. Injac et al.

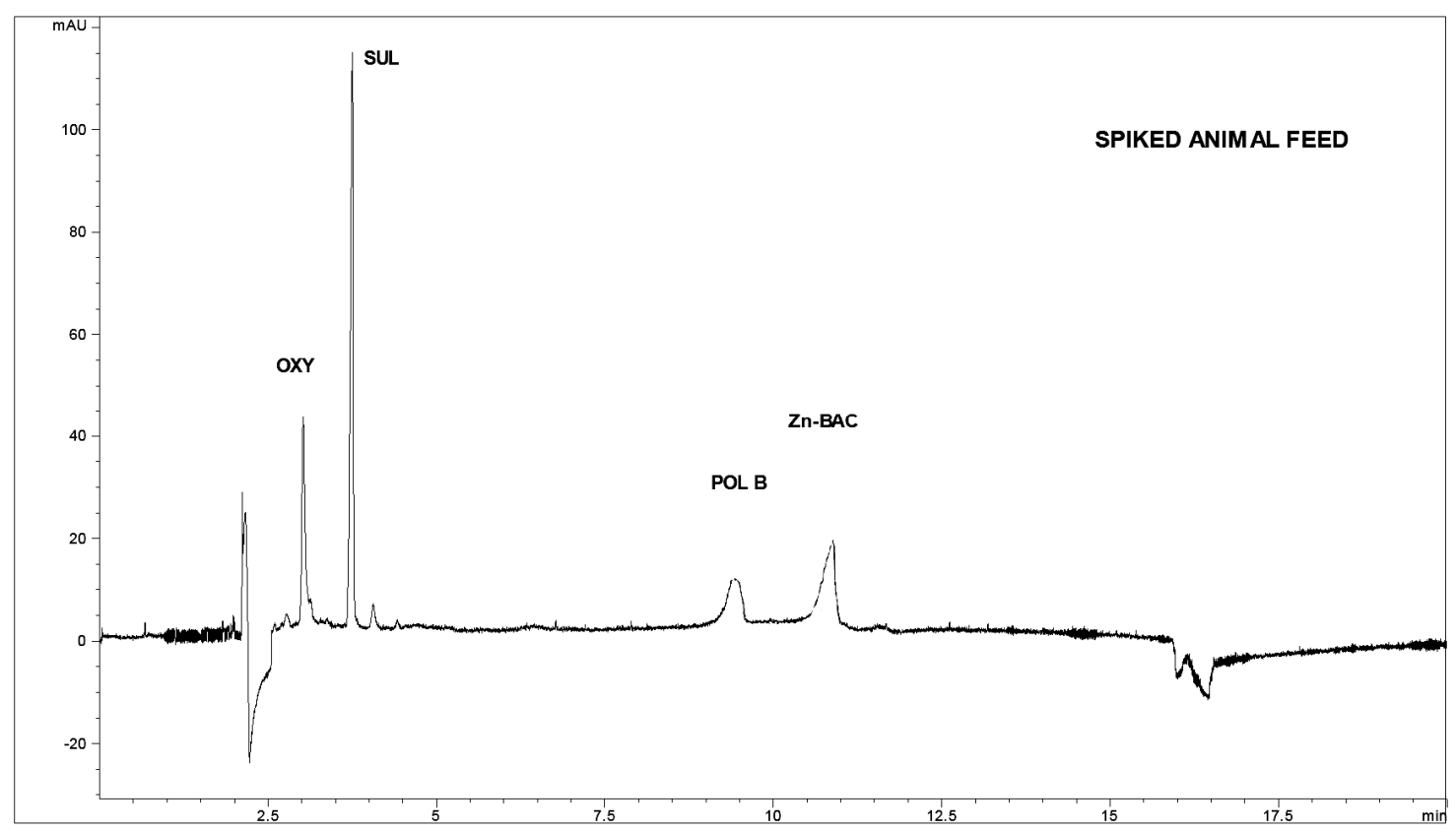

30

31

32

33

34

35

36

37

38

39

40

41

42

43

44

45

46

47

48

49

50

51

52

53

54

55

56

57

58

59

60

http://mc.manuscriptcentral.com/tfac Email: fac@tandf.co.uk 